\title{
Dissolution of Neptunium and Plutonium Oxides Using a Catalyzed Electrolytic Process
}

October 2004

Prepared by

T. D. Hylton

R. R. Brunson

A. S. Icenhour

L. M. Toth

R. M. Wham 


\section{DOCUMENT AVAILABILITY}

Reports produced after January 1, 1996, are generally available free via the U.S. Department of Energy (DOE) Information Bridge:

Web site: http://www.osti.gov/bridge

Reports produced before January 1, 1996, may be purchased by members of the public from the following source:

National Technical Information Service

5285 Port Royal Road

Springfield, VA 22161

Telephone: 703-605-6000 (1-800-553-6847)

TDD: 703-487-4639

Fax: 703-605-6900

E-mail: info@ntis.fedworld.gov

Web site: http://www.ntis.gov/support/ordernowabout.htm

Reports are available to DOE employees, DOE contractors, Energy Technology Data Exchange (ETDE) representatives, and International Nuclear Information System (INIS) representatives from the following source:

Office of Scientific and Technical Information

P.O. Box 62

Oak Ridge, TN 37831

Telephone: 865-576-8401

Fax: 865-576-5728

E-mail: reports@adonis.osti.gov

Web site: http://www.osti.gov/contact.html

This report was prepared as an account of work sponsored by an agency of the United States Government. Neither the United States government nor any agency thereof, nor any of their employees, makes any warranty, express or implied, or assumes any legal liability or responsibility for the accuracy, completeness, or usefulness of any information, apparatus, product, or process disclosed, or represents that its use would not infringe privately owned rights. Reference herein to any specific commercial product, process, or service by trade name, trademark, manufacturer, or otherwise, does not necessarily constitute or imply its endorsement, recommendation, or favoring by the United States Government or any agency thereof. The views and opinions of authors expressed herein do not necessarily state or reflect those of the United States Government or any agency thereof. 
ORNL/TM-2004/211

Nuclear Science and Technology Division

\title{
DISSOLUTION OF NEPTUNIUM AND PLUTONIUM OXIDES USING A CATALYZED ELECTROLYTIC PROCESS
}

T. D. Hylton

R. R. Brunson

A. S. Icenhour

L. M. Toth*

R. M. Wham

Date Published: October 2004

\author{
Prepared by \\ OAK RIDGE NATIONAL LABORATORY \\ P.O. Box 2008 \\ Oak Ridge, Tennessee 37831-6283 \\ managed by \\ UT-Battelle, LLC \\ for the \\ U.S. DEPARTMENT OF ENERGY \\ under contract DE-AC05-00OR22725
}

*Harbach Engineering and Solutions 



\section{CONTENTS}

Page

ACKNOWLEDGMENTS $\ldots \ldots \ldots \ldots \ldots \ldots \ldots \ldots \ldots \ldots \ldots \ldots \ldots \ldots \ldots \ldots \ldots \ldots \ldots \ldots \ldots$

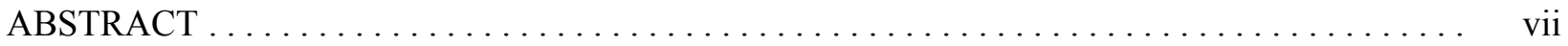

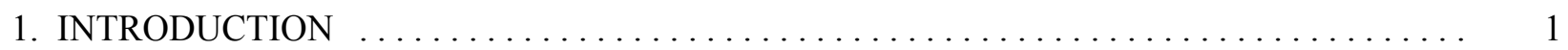

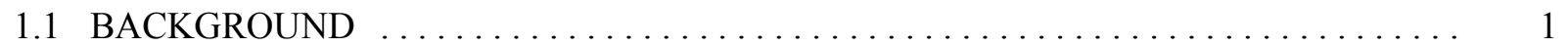

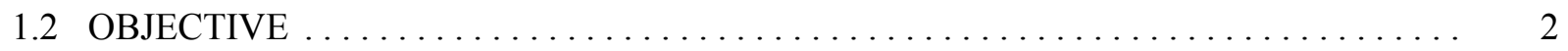

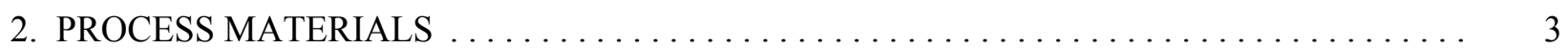

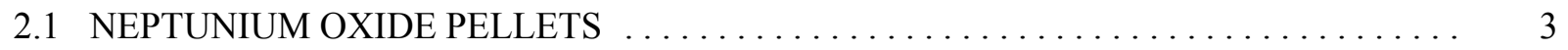

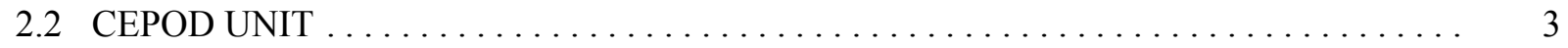

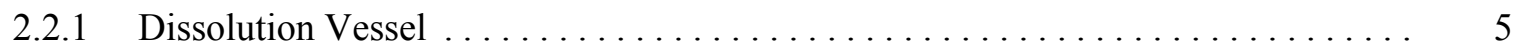

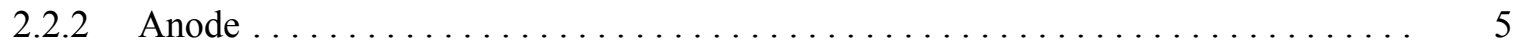

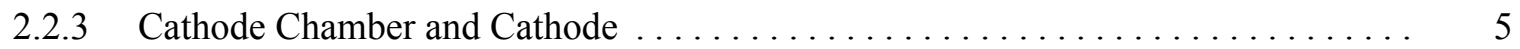

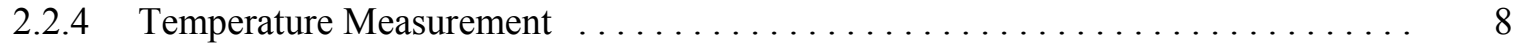

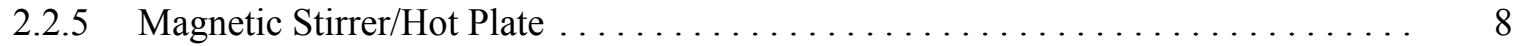

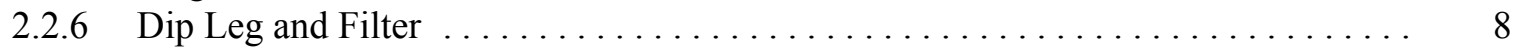

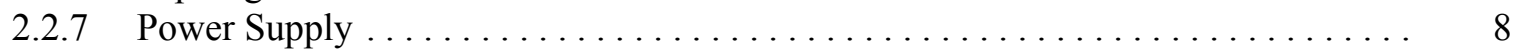

2.2 .8 Anolyte . . . . . . . . . . . . . . . . . . . . . . . . . . . . . 10

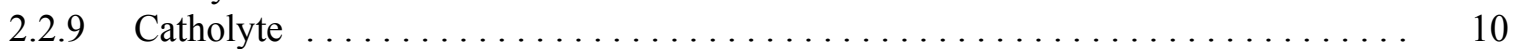

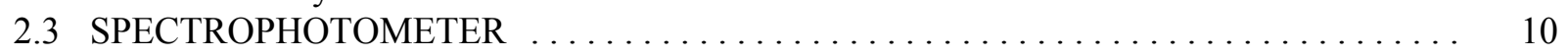

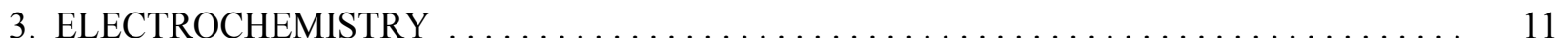

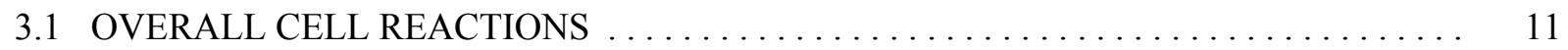

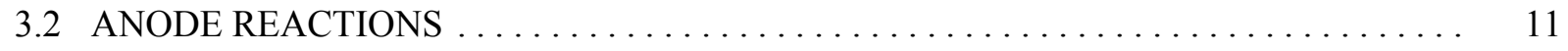

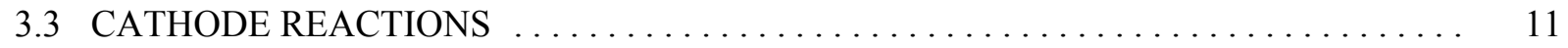

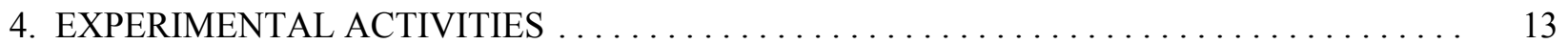

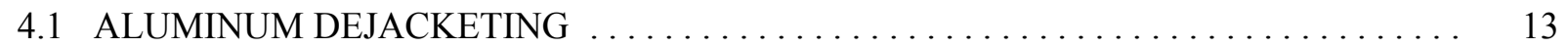

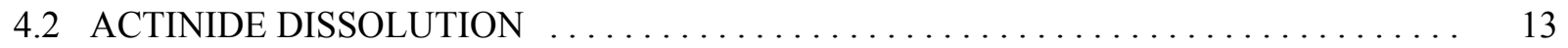

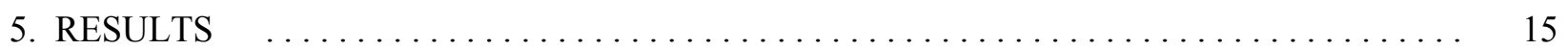

5.1 LABORATORY ANALYSES OF SAMPLES $\ldots \ldots \ldots \ldots \ldots \ldots \ldots \ldots \ldots \ldots \ldots$

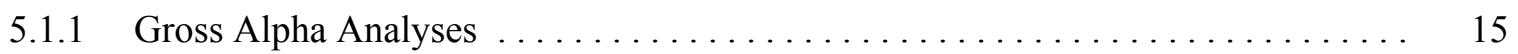

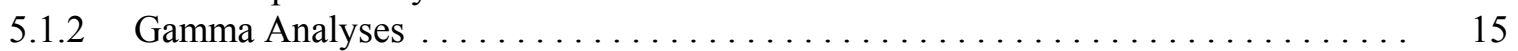

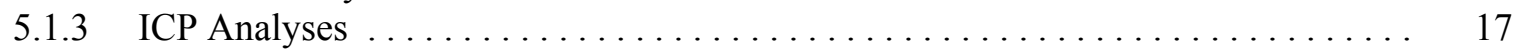

5.2 SPECTROPHOTOMETER ANALYSIS OF SAMPLES $\ldots \ldots \ldots \ldots \ldots \ldots \ldots \ldots \ldots \ldots$

6. SUMMARY AND RECOMMENDATIONS $\ldots \ldots \ldots \ldots \ldots \ldots \ldots \ldots \ldots \ldots \ldots \ldots$

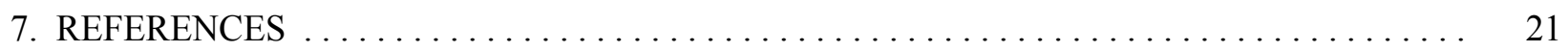

APPENDIX A. ANALYTICAL SAMPLE RESULTS $\ldots \ldots \ldots \ldots \ldots \ldots \ldots \ldots \ldots \ldots \ldots$ 



\section{ACKNOWLEDGMENTS}

The authors of this report would like to acknowledge certain individuals and organizations for their contributions that helped to ensure the success of the project.

Cold testing of the CEPOD unit was performed at the Radiochemical Engineering Development Center (Building 7920). The dissolution of the irradiated pellets was performed in a hot cell at the Radioactive Materials Analytical Laboratory (Building 2026). J. M. Giaquinto and R. D. Canaan performed the analyses on the samples. M. A. Delph and L. E. Duncan provided radiation protection assistance. R. D. Vandergrift, D. L. Denton, and C. E. Benson provided technical support to the project, and M. K. Savage provided technical editing for this report. 



\begin{abstract}
This report discusses the scoping study performed to evaluate the use of a catalyzed electrolytic process for dissolving ${ }^{237} \mathrm{~Np}$ oxide targets that had been irradiated to produce ${ }^{238} \mathrm{Pu}$ oxide. Historically, these compounds have been difficult to dissolve, and complete dissolution was obtained only by adding hydrofluoric acid to the nitric acid solvent. The presence of fluoride in the mixture is undesired because the fluoride ions are corrosive to tank and piping systems and the fluoride ions cause interferences in the spectrophotometric analyses. The goal is to find a dissolution method that will eliminate these issues and that can be incorporated into a processing system to support the domestic production and purification of ${ }^{238} \mathrm{Pu}$. This study evaluated the potential of cerium(IV) ions, a strong oxidant, to attack and dissolve the oxide compounds. In the dissolution process, the cerium(IV) ions are reduced to cerium(III) ions, which are not oxidants. Therefore, an electrolytic process was incorporated to continuously convert cerium(III) ions back to cerium(IV) ions so that they can dissolve more of the oxide compounds. This study showed that the neptunium and plutonium oxides were successfully dissolved and that more development work should be performed to optimize the procedure.
\end{abstract}





\section{INTRODUCTION}

\subsection{BACKGROUND}

The U.S. Department of Energy (DOE) Office of Space and Defense Power, NE-50, is reestablishing domestic production of ${ }^{238} \mathrm{Pu}$ to support the needs of the National Aeronautics and Space Administration (NASA). The feed material for the production of ${ }^{238} \mathrm{Pu}$ is ${ }^{237} \mathrm{~Np}$, which is currently stored at the Savannah River Site. The neptunium will be stabilized as an oxide, packaged, and transported to the Y-12 National Security Complex for interim storage. The material will then be transferred, as needed, to the Radiochemical Engineering Development Center (REDC) at the Oak Ridge National Laboratory (ORNL), where the neptunium oxide will be dissolved, purified, resolidified, blended with aluminum oxide, pressed into pellets, and fabricated into aluminum target rods. The target rods will be transferred to and irradiated at the High Flux Isotope Reactor (HFIR) at ORNL and/or the Advanced Test Reactor (ATR) at the Idaho National Engineering and Environmental Laboratory to convert the ${ }^{237} \mathrm{~Np}$ into ${ }^{238} \mathrm{Pu}$. The irradiated targets will be returned to ORNL, where they will undergo chemical processing to recover and purify the desired ${ }^{238} \mathrm{Pu}$ product and also to recover and purify the portion of the ${ }^{237} \mathrm{~Np}$ that was not converted during the irradiation cycle. The ${ }^{237} \mathrm{~Np}$ that is recovered from the irradiated targets will be recycled into targets for additional irradiation.

REDC is the production, storage, and distribution center for the heavy-element research program of the DOE. REDC is a unique facility that is capable of handling highly active alpha-emitting radionuclides with high gamma and neutron radiation fields. The facility contains heavily shielded hot cells and laboratories for process development, process-control analysis, final product purification, and packaging operations. Where needed, the laboratories are equipped with alpha-containment equipment (e.g., glove boxes). REDC staff have extensive experience ranging from basic R\&D to pilot-scale demonstration of fuel cycle separation technologies and have obtained vast experience in performing radiochemical separations. The process flow sheet for the production of ${ }^{238} \mathrm{Pu}$ is similar to that successfully and effectively demonstrated by the REDC staff for approximately 40 years.

In order to recover the plutonium and neptunium isotopes from the irradiated targets, ${ }^{1}$ the aluminum (from the target rods and blended matrix) is first separated from the actinides by a controlled dissolution of the aluminum in a caustic nitrate solution. The actinides remain undissolved in the caustic nitrate solution, and the dissolved aluminum mixture is separated by filtration of the caustic nitrate solution. Historically, the actinides in the oxide state have shown resistance to dissolution through normal acid additions. Traditionally, fluoride ions (as HF or NaF) have been added to heated nitric acid solutions to 
effectively promote the dissolution of both $\mathrm{NpO}_{2}$ and $\mathrm{PuO}_{2}$. However, the addition of hydrofluoric acid to the mixture is undesirable because the fluoride ions (1) are corrosive to metal and glass surfaces and (2) cause problems with the in-line spectrophotometric measurements used to monitor valence states in the subsequent purification processes. Thus, another method to dissolve the actinide material that would eliminate these disadvantages would be preferable. One potential method uses cerium(IV) ions to promote the dissolution of the actinide compounds.

In the 1970s, researchers at ORNL evaluated the use of cerium as an alternative to fluoride in promoting rapid dissolution of $\mathrm{PuO}_{2}$ in nitric acid. Their results showed that $\mathrm{Ce}^{4+}$ ions promoted the dissolution. The researchers noted that the $\mathrm{Ce}^{4+}$ was reduced to $\mathrm{Ce}^{3+}$ during the dissolution and that the $\mathrm{Ce}^{3+}$ must be reoxidized electrolytically or with ozone. The presence of ruthenium, a fission product, was found to have a negative effect because it would readily reduce the $\mathrm{Ce}^{4+}$ ions to $\mathrm{Ce}^{3+}$ ions. $^{2}$

In 1974, catalyzed electrolytic plutonium oxide dissolution (CEPOD) was demonstrated at Pacific Northwest Laboratory to dissolve plutonium-containing residues remaining after the dissolution of spent mixed-oxide reactor fuels. Ryan et al. discuss this demonstration, along with the history of using $\mathrm{Ce}^{4+}$ to increase the rate of dissolution by nitric acid. Ryan also presents the chemistry involved in CEPOD and the results of its application to the dissolution of the plutonium content of a variety of $\mathrm{PuO}_{2}$-containing materials. The researchers also investigated other metal ion pairs (such as $\mathrm{Ag}^{2+} / \mathrm{Ag}^{1+}$ ) for the oxidation process. $^{3}$

The use of a CEPOD unit was recognized as a method that would eliminate the problems caused by the fluoride ions. By continuously regenerating the ions to the higher valence state, the amount of catalyst (e.g., cerium) that is required to dissolve the actinide compounds can be reduced. A disadvantage of the CEPOD process is that when the dissolution of the actinides is complete, the solution also contains the cerium ions (or other metal ion pairs), which will need to be separated from the actinides in order to obtain a pure product. Historical experience has indicated that the separation of the cerium ions from the actinide ions is achievable.

\subsection{OBJECTIVE}

This project examined the use of a CEPOD unit to dissolve neptunium oxide pellets that had been irradiated in the ATR. Cerium ions were selected as the oxidant metal pair because some cerium already exists in the targets, and the use of cerium ions does not create the potential for a hazardous waste (as defined by the Resource Conservation and Recovery Act). 


\section{PROCESS MATERIALS}

The major materials used in this experiment included the irradiated neptunium oxide pellets, the CEPOD unit, and a spectrophotometer.

\subsection{NEPTUNIUM OXIDE PELLETS}

The pellet design was based on the curium-aluminum pellets that have been fabricated at REDC for irradiation in the HFIR. The pellet core of $\mathrm{NpO}_{2}$ and aluminum powders are clad in a thin-wall aluminum liner with a bottom and top cap of pressed aluminum powder. The bottom cap aluminum powder is pressed into the liner. The $\mathrm{NpO}_{2}$ powder and aluminum powder mixture is then poured into the capped liner, and a final slug of aluminum powder is added to the liner, which serves as the top cap when the pellet is compressed to either 80 or $90 \%$ of the theoretical density. A detailed description of the pellet fabrication process is provided in other reports. ${ }^{4,5}$

The dissolution involved three neptunium oxide pellets that were identified as NP-09, NP-20, and NP-21. Characterization data for these pellets prior to irradiation are reported by Wham et al. and are provided in Table 1.4

Table 1. Characterization data for neptunium oxide pellets prior to irradiation ${ }^{a}$

\begin{tabular}{ccccc}
\hline $\begin{array}{c}\text { Pellet } \\
\text { ID }\end{array}$ & $\begin{array}{c}\mathrm{NpO}_{2} \text { mass } \\
(\mathrm{g})\end{array}$ & $\begin{array}{c}\mathrm{Np} \text { mass } \\
(\mathrm{g})\end{array}$ & $\begin{array}{c}\mathrm{NpO}_{2} \\
(\mathrm{Vol} \%)\end{array}$ & $\begin{array}{c}\text { Pellet density } \\
\text { \% theoretical })\end{array}$ \\
\hline $\mathrm{NP}-09$ & 0.4341 & 0.3825 & 19.35 & 87.61 \\
$\mathrm{NP}-20$ & 0.2166 & 0.1908 & 9.63 & 89.96 \\
$\mathrm{NP}-21$ & 0.2163 & 0.1906 & 9.61 & 91.00 \\
\hline
\end{tabular}

${ }^{a}$ Data obtained from Wham et al., ORNL/TM-2004/170 [ref. 4].

\subsection{CEPOD UNIT}

A CEPOD unit is a two-compartment cell, with each cell containing an electrode. The solutions in the two compartments are kept separated by a porous barrier, which is necessary to minimize solution mixing while permitting electrical conductivity. The mixing of the solutions in the two compartments must be minimized because nitric acid reduction products in the catholyte will rapidly reduce the cerium(IV) ions if they enter the anode chamber. 
Figure 1 is a schematic of the CEPOD unit that was developed for this demonstration. Whenever possible, off-the-shelf materials were used. The major components of the CEPOD unit included the dissolution vessel, the anode, the cathode, the cathode chamber, the temperature sensor, the magnetic stirrer/hot plate, the dip leg and filter, and the power supply. These components are described below.

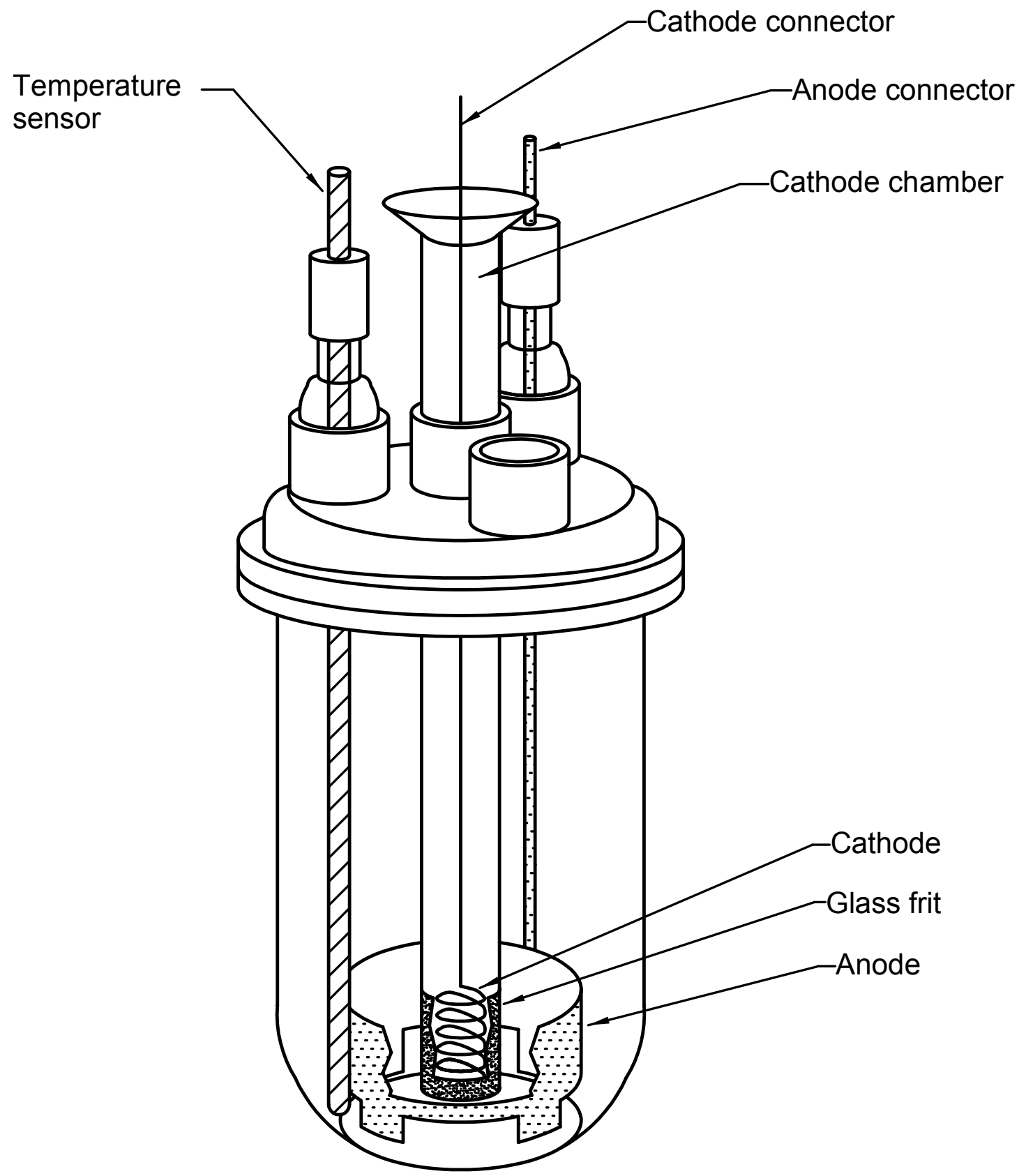

Fig. 1. Schematic diagram of dissolver vessel. Cutaways of the anode and the glass frit section are included for clarity. A dip leg with a $2-\mu \mathrm{m}$ filter, which is not shown in the drawing, was inserted in the open position to allow fluids to be added to and removed from the anode compartment. 


\subsubsection{Dissolution Vessel}

Glass was selected as the material of construction for the dissolution vessel because it is not attacked by the cerium(IV) ions and would permit visual observations. The vessel was a glass kettle with a flanged lid and a nominal volume capacity of $1 \mathrm{~L}$. The lid included four standard taper joint openings. The dissolution vessel has a nominal height of $222 \mathrm{~mm}$ (8.75 in.) and a diameter of $111 \mathrm{~mm}$ (4.375 in.). The standard tapered openings in the lid permitted the inclusion of the anode, the cathode and cathode chamber, the dip leg, and the temperature sensor.

\subsubsection{Anode}

The dissolution of the actinides occurs in the area of the dissolution vessel that includes the anode. A schematic of the anode is shown in Fig. 2. It consisted of a hollow platinum cylinder that was welded to a rod, which extended through one of the standard taper openings in the lid. The rod was $\sim 254 \mathrm{~mm}$ (10 in.) in length and had a diameter of $\sim 3 \mathrm{~mm}$ (1/8 in.). It was fabricated of $90 \%$ platinum $/ 10 \%$ rhodium alloy (which has more rigidity than pure platinum). The cylindrical portion of the anode, which was fabricated from platinum, was $25 \mathrm{~mm}$ (1 in.) high by 73-mm (2.875-in.) diam and $0.25 \mathrm{~mm}$ (0.010 in.) thick. The bottom of the cylindrical section was outfitted with four legs, which were $19 \mathrm{~mm}(0.75 \mathrm{in}$.) high by $13 \mathrm{~mm}$ ( $0.5 \mathrm{in}$.) wide, to support the electrode off the bottom of the dissolution vessel. The surface area (one side) of the cylindrical portion (including the legs) was $67.7 \mathrm{~cm}^{2}\left(10.5 \mathrm{in.}^{2}\right)$.

\subsubsection{Cathode Chamber and Cathode}

The cathode chamber was designed and fabricated for placement in the center standard taper opening of the lid of the dissolution vessel. A schematic of the cathode chamber is shown in Fig. 3. A glass frit on the bottom of the chamber provided the physical separation between the fluids in the two chambers, yet permitted the transfer of ions. The frit, which was acquired from Ace Glass as a solid cylinder $(25 \mathrm{~mm}$ high by $18-\mathrm{mm}$ diam), was defined as having a pore size ranging from 4 to $9 \mu \mathrm{m}$ (Ace Glass porosity E). A hole, which was $\sim 23 \mathrm{~mm}$ in depth and 14-mm diam. (0.9 in. by 0.55-in. diam), was bored into the frit to increase the surface area through which the ions are transferred. The glass frit was joined to a section of 18-mm-OD standard-wall Pyrex glass tubing, which was joined to a standard taper joint. A 51-mm (2in.) section of glass tubing (22-mm OD) with a flared lip was positioned above the standard taper joint.

The cathode was fabricated from a piece of stainless steel welding rod. As shown in Fig. 1, the bottom portion of the rod was spiraled to increase the surface area. The cathode extended above the top of the cathode chamber so that it could be connected to the power supply. 


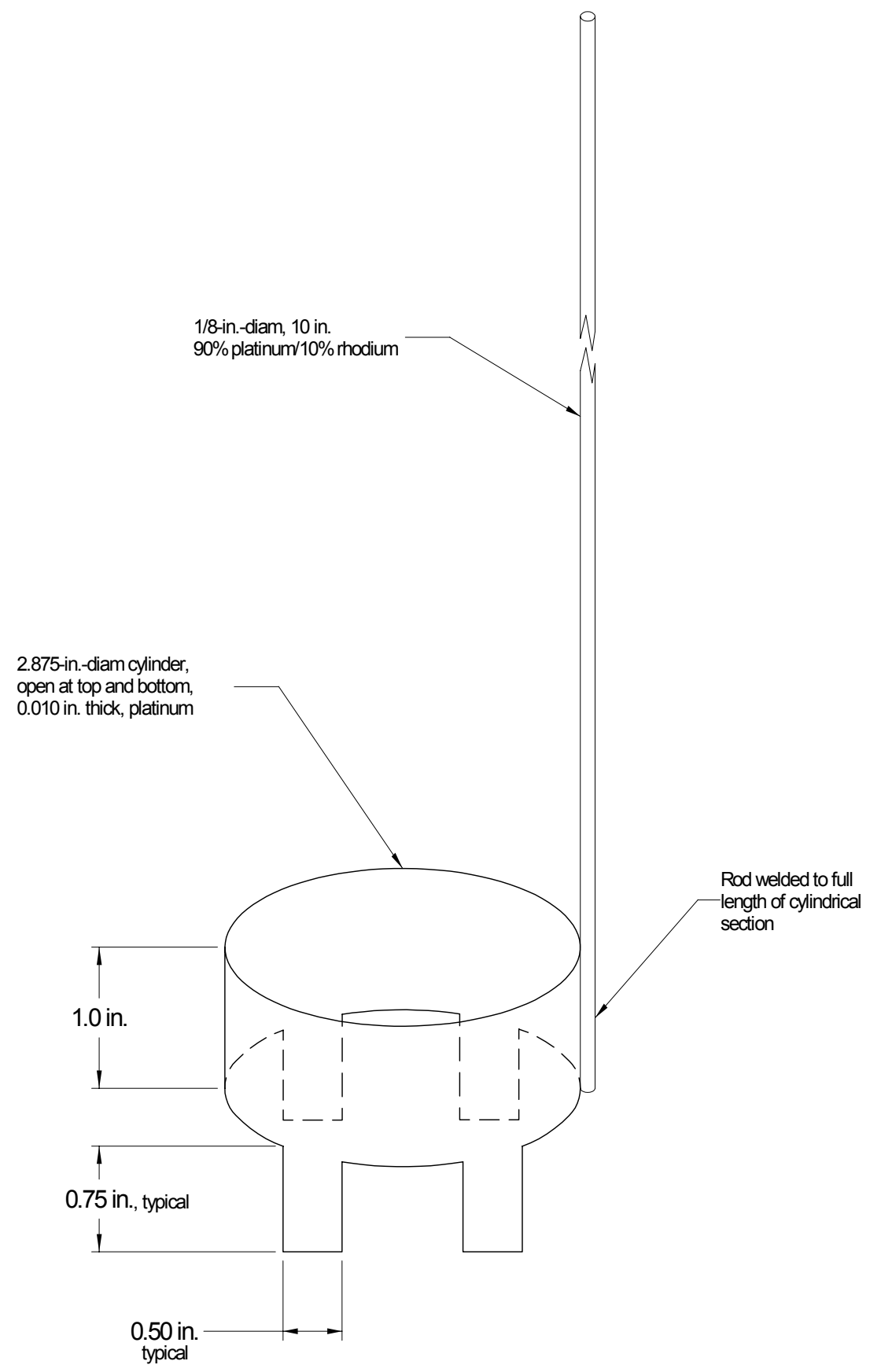

Fig. 2. Schematic diagram of anode. 


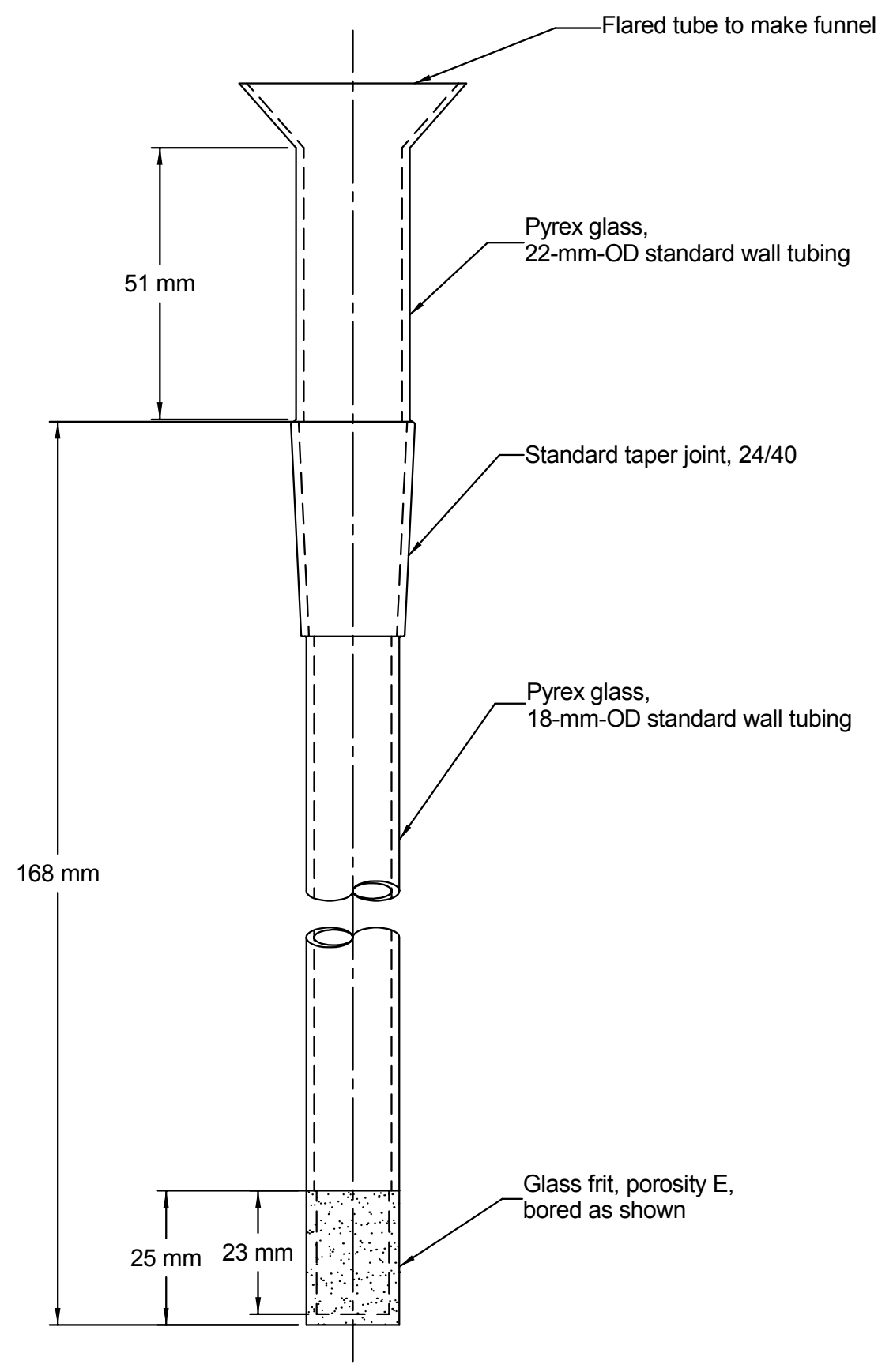

Fig. 3. Schematic diagram of cathode chamber. 


\subsubsection{Temperature Measurement}

The temperature of the fluid in the dissolution vessel was measured with a resistance temperature detector (RTD). The RTD was fabricated with a titanium sheath to protect it from attack by the cerium(IV) ions.

\subsubsection{Magnetic Stirrer/Hot Plate}

The solution in the dissolution vessel was stirred by a magnetic stirrer/hot plate. A 1-in. Teflon-coated magnetic stirring bar (not shown in Fig. 1) was used in the anode chamber to continuously mix the solution to maximize the contact with the actinide solid particles and to continuously bring the cerium(III) ions back to the anode for reconversion to cerium(IV) ions.

Heating of the solution was performed through the hot plate portion of the unit. An aluminum block was placed between the glass pot and the hot plate to help to distribute the heat evenly to the glass pot. The passing of electrical current between the anode and cathode also provided some joule heating to the solution.

\subsubsection{Dip Leg and Filter}

A dip leg (not shown in Fig. 1) was fabricated from 6.35-mm (0.25-in.) titanium tubing and inserted in the dissolution vessel through a fitting in the lid. A schematic of the dip leg is shown in Fig. 4. A 2- $\mu \mathrm{m}$ stainless steel sintered-metal filter was connected to the top of the dip leg. Chemical additions and solution withdrawals were made through the dip leg by a peristaltic pump. Although the filter was stainless steel, it was deemed adequate for this application because the cerium(IV) ions would not have much contact time with the filter itself. Sintered metal filters fabricated from metals that were not attacked by the cerium(IV) ions were not available as off-the-shelf items, and special fabrication of a filtering unit was cost prohibitive. The offset in the dip leg was to position the filter away from the cathode chamber.

\subsubsection{Power Supply}

Electrical current to the anode and cathode [i.e., for converting the cerium(III) ions to cerium(IV) ions] was provided with a direct current power supply, which was positioned outside the hot cell. Electrical connections from the power supply to the anode and cathode were made with alligator clips. A variable transformer was used to regulate the electrical current from the power supply to the anode and cathode. 


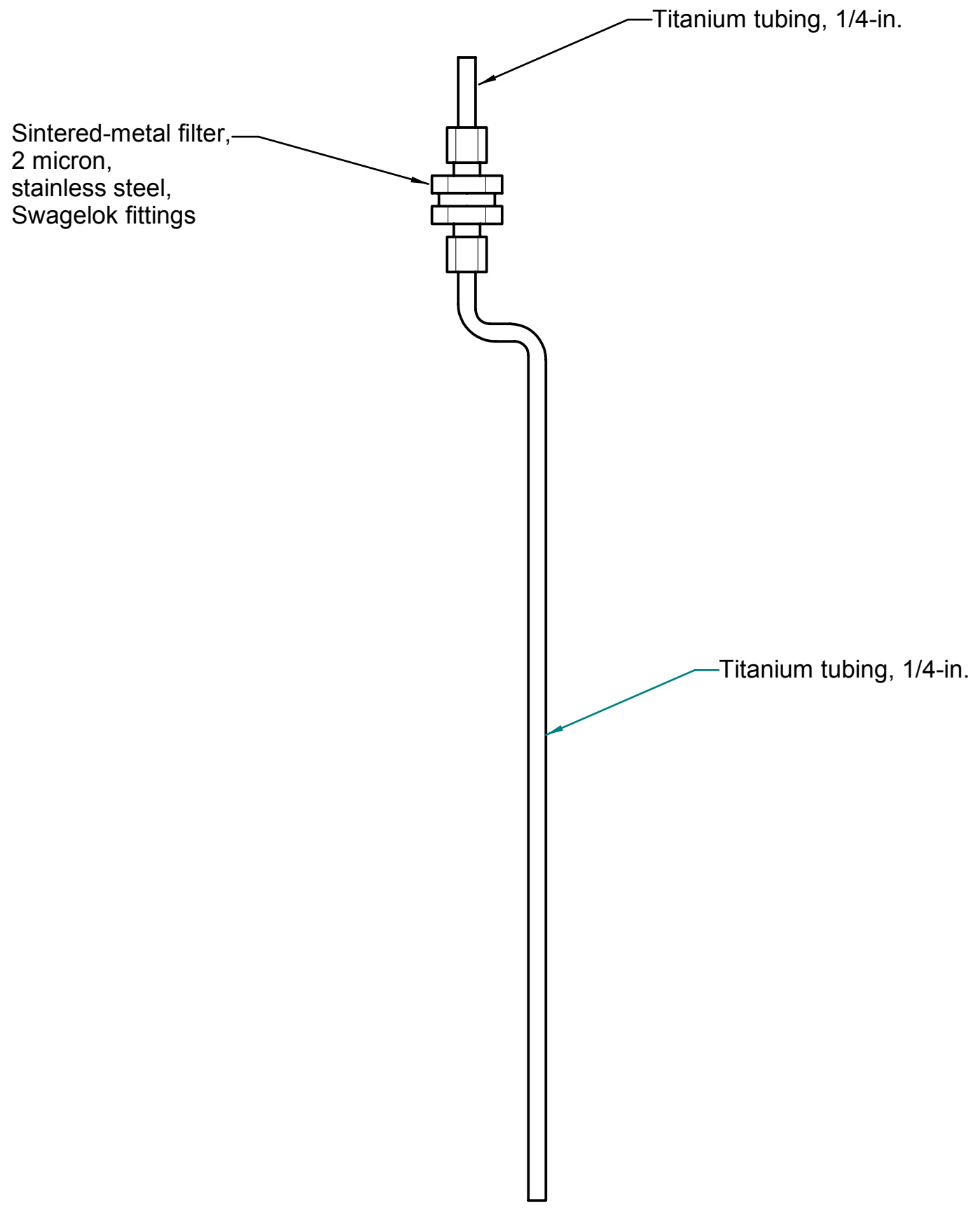

Fig. 4. Schematic diagram of dip tube and sintered-metal filter. 
The power supply contained an internal calibrated resistor (i.e., a shunt) by which the voltage drop could be measured. The corresponding current could then be calculated by Ohm's law.

\subsubsection{Anolyte}

The anolyte solution was prepared as $4 \mathrm{MHNO}_{3}-0.15 \mathrm{MCe}$, using cerous nitrate hexahydrate. The bulk of the cerium was converted to cerium(IV) using the CEPOD unit prior to the actinide dissolution. During the process, the conversion of cerium(III) to cerium(IV) was qualitatively verified as the color of the solution changed from transparent to orangish brown. The cerium(IV) content was later verified by the baseline analysis of the anolyte solution with the spectrophotometer.

\subsubsection{Catholyte}

Nitric acid ( $8 M$ ) was used for the catholyte solution. The electrolytic process consumes acid in the cathode chamber (see Sect. 3.3). Therefore, subsequent aliquots of the $8 M \mathrm{HNO}_{3}$ were added intermittently to replenish the acid concentration. The need to replenish the acid in the cathode chamber was recognized by a drop in the electrical current to the CEPOD unit. After acid was added, the current would reestablish itself. In a more developed process, it would be desirable to monitor the cathode solution (e.g., conductivity) and add acid on a more proactive basis. For example, acid could be added through an intermittent drip to the cathode chamber. Monitoring the conductivity of the cathode solution would help determine the appropriate addition rate.

\subsection{SPECTROPHOTOMETER}

During the course of the $\mathrm{Np} / \mathrm{Pu}$ oxide electrolytic dissolution, the progress of the dissolution was followed using absorption spectrophotometry. Samples were periodically withdrawn and placed in a 1-cm spectrophotometric cell, and the absorption of the sample was measured from 1300 to $400 \mathrm{~nm}$ using a Cary 17DH spectrophotometer equipped with digital output. A Hellma fiber-optic system carried the spectrophotometer's light beams into and out of the hot cell. Using this analytical system, the species identity and concentration were both determined by comparison with known calibration spectra. ${ }^{6,7}$ Typically, absorption bands for $\mathrm{NpO}_{2}{ }^{2+}$ and $\mathrm{PuO}_{2}{ }^{2+}$ were found at 1220 and $830 \mathrm{~nm}$, respectively. After measurement, the sample can be returned to the electrolytic cell to mix with the bulk solution. 


\section{ELECTROCHEMISTRY}

The irradiated neptunium pellets contain plutonium, neptunium, and fission products. Although the discussion of electrochemistry in Sects. 3.1 through 3.3 focuses primarily on the plutonium species, the dissolution of the other species occur via similar methodology.

\subsection{OVERALL CELL REACTIONS}

Upon dissolution of the plutonium oxide, the plutonyl ion is generated. Equations (1) and (2) illustrate the desired overall cell reactions in the CEPOD process.

$$
\begin{aligned}
& \mathrm{PuO}_{2}+2 \mathrm{NO}_{3}^{-}+4 \mathrm{H}^{+} \longrightarrow \mathrm{PuO}_{2}{ }^{2+}+2 \mathrm{NO}_{2}+2 \mathrm{H}_{2} \mathrm{O} \\
& 3 \mathrm{PuO}_{2}+2 \mathrm{NO}_{3}^{-}+8 \mathrm{H}^{+} \longrightarrow 3 \mathrm{PuO}_{2}{ }^{2+}+2 \mathrm{NO}+4 \mathrm{H}_{2} \mathrm{O}
\end{aligned}
$$

In reality, the reduction of nitrate ions can be more complex, particularly at high current densities. Other researchers have observed the production of compounds such as $\mathrm{N}_{2} \mathrm{O}, \mathrm{N}_{2}$, and $\mathrm{NH}_{4}^{+}{ }^{3}$ The reactions that occur in a CEPOD unit are complex and are a function of transference numbers, ionic concentrations, amperage, and the relative extent of the various electrode reactions that occur at the anode and the cathode.

\subsection{ANODE REACTIONS}

The primary reactions that occur in the anode compartment are shown in Eqs. (3) through (6). The reactions shown in Eqs. (3) and (4) occur at the anode surface. These reactions increase the net positive charge in the anode compartment.

$$
\begin{aligned}
& \mathrm{Ce}^{3+} \longrightarrow \mathrm{Ce}^{4+}+\mathrm{e}^{-} \\
& 2 \mathrm{H}_{2} \mathrm{O} \longrightarrow \mathrm{O}_{2}+4 \mathrm{H}^{+}+4 \mathrm{e}^{-} \\
& 2 \mathrm{Ce}^{4+}+\mathrm{PuO}_{2} \longrightarrow \mathrm{PuO}_{2}{ }^{2+}+2 \mathrm{Ce}^{3+} \\
& 2 \mathrm{Ce}^{4+}+\mathrm{H}_{2} \mathrm{O} \longrightarrow 2 \mathrm{Ce}^{3+}+2 \mathrm{H}^{+}+0.5 \mathrm{O}_{2}
\end{aligned}
$$

The formal potential for the reaction shown in Eq. (3) in $4 M \mathrm{HNO}_{3}$ is $1.6 \mathrm{~V}$.

\subsection{CATHODE REACTIONS}

The overall reactions that occur in the cathode compartment are shown in Eqs. (7) and (8). Other compounds, such as $\mathrm{N}_{2} \mathrm{O}, \mathrm{N}_{2}$, and $\mathrm{NH}_{4}^{+}$, may be produced at certain acidities, particularly at high current density. Hydrogen gas is expected to be produced at low acidity. The production of hydrogen is 
undesirable for two reasons. First, a safety hazard would be introduced if the concentration of hydrogen was within the combustible range. Second, hydrogen embrittlement can occur in certain metals (such as titanium) that may be used in the CEPOD unit. The production of hydrogen in the cathode compartment may be reduced by keeping the acid concentration high (above 4-6 $M \mathrm{HNO}_{3}$ ). These reactions consume more $\mathrm{H}^{+}$than $\mathrm{NO}_{3}^{-}$and thus raise the negative charge in the cathode compartment. As a result, the addition of acid to the cathode compartment is required.

$$
\begin{aligned}
& 2 \mathrm{H}^{+}+\mathrm{NO}_{3}{ }^{-}+\mathrm{e}^{-} \longrightarrow \mathrm{NO}_{2}+\mathrm{H}_{2} \mathrm{O} \\
& 4 \mathrm{H}^{+}+\mathrm{NO}_{3}{ }^{-}+3 \mathrm{e}^{-} \longrightarrow \mathrm{NO}+2 \mathrm{H}_{2} \mathrm{O}
\end{aligned}
$$




\section{EXPERIMENTAL ACTIVITIES}

The CEPOD unit was set up in a hot cell in Building 2026 at ORNL. The test was conducted to simulate the aluminum dejacketing and the actinide dissolution. For the aluminum dejacketing portion of the process, a reflux condenser (cooled by recirculated chilled water) was used on the dissolution vessel, and the cathode chamber was set aside. The dejacketing process also removes a large portion of the fission products. For the actinide dissolution, the reflux condenser was removed and the cathode chamber was inserted.

\subsection{ALUMINUM DEJACKETING}

The three irradiated neptunium oxide pellets (NP-09, NP-20, and NP-21) were retrieved and placed in the dissolution vessel with approximately $200 \mathrm{~mL}$ of $2.2 \mathrm{M}$ sodium nitrate. The solution was stirred with a magnetic stirring bar and heated to approximately $90-96^{\circ} \mathrm{C}$. Sodium hydroxide $(60 \mathrm{~mL}$ of $10 \mathrm{M})$ was metered into the sodium nitrate solution at a rate of $\sim 1 \mathrm{~mL} / \mathrm{min}$. Metering of the caustic into the mixture was necessary because of the exothermic reaction that occurs from the dissolution of the aluminum. After all the $\mathrm{NaOH}$ had been added, the temperature was increased to approximately $104^{\circ} \mathrm{C}$ and the solution was digested for approximately $4 \mathrm{~h}$. After the digestion period, the solution was cooled to $<50^{\circ} \mathrm{C}$ and allowed to settle. The liquid was decanted slowly through the dip leg and a $2-\mu \mathrm{m}$ sintered-metal filter by a peristaltic pump into a 500-mL volumetric flask. Approximately $120 \mathrm{~mL}$ of $2 \mathrm{M} \mathrm{NaOH}$ was backflushed through the filter into the dissolution vessel. The solution was stirred in the dissolution vessel to wash the solid particles and then allowed to settle. The supernatant was decanted to the $500-\mathrm{mL}$ volumetric flask. A second aliquot of $\sim 120 \mathrm{~mL}$ of $2 \mathrm{M} \mathrm{NaOH}$ was added as a backflush of the filter into the dissolution vessel, and the wash process and decanting to the $500-\mathrm{mL}$ volumetric flask were repeated. The actinide product remained as undissolved solid particles in the dissolution vessel. The volume of the solution in the volumetric flask was adjusted to $500 \mathrm{~mL}$ with $2 \mathrm{M} \mathrm{NaOH}$. The solution was mixed and sampled, and the sample was submitted for laboratory analysis.

\subsection{ACTINIDE DISSOLUTION}

Approximately $300 \mathrm{~mL}$ of $4 \mathrm{MHNO}_{3}-0.15 \mathrm{MCe}\left(\mathrm{as} \mathrm{Ce}^{4+}\right.$ ) solution was added to the dissolution vessel while backflushing the 2- $\mu \mathrm{m}$ filter. Approximately $20 \mathrm{~mL}$ of $8 M \mathrm{HNO}_{3}$ was added to the cathode chamber, which was then inserted into the vessel. The power cables were connected to the anode and cathode by alligator clips. Direct current was applied to the electrodes at approximately 3 A (nominal voltage $=3 \mathrm{~V}$ ). The magnetic stirrer was turned on, and the solution was heated to approximately $60-80^{\circ} \mathrm{C}$. At room temperature, the cerium(IV) ions are not very active; however, as the temperature 
increases, the activity becomes more pronounced. Nitric acid ( $8 M$ ) was intermittently added to the cathode chamber to replenish the acid that was consumed by the electrochemical reaction at the cathode.

Because neither the dissolution rate nor the total digestion time required for complete dissolution was known, samples of the anolyte solution were collected at nominal 1-h intervals (referenced to the time that the solution reached $60^{\circ} \mathrm{C}$ ). The samples were collected by recirculating fluid through the dip leg and the $2-\mu \mathrm{m}$ filter back to the anolyte chamber to purge the solution out of the tubing and then pumping the filtered sample into a sample bottle. An aliquot of the sample (approximately $3 \mathrm{~mL}$ ) was transferred to a 1-cm spectrophotometric cell and analyzed in the hot cell via the spectrophotometer. Prior to performing the dissolution test, a sample of the $4 \mathrm{MHNO}_{3}-0.15 \mathrm{M}$ Ce solution was analyzed with the spectrophotometer to obtain a baseline spectra. By comparing the spectra at various times in the dissolution process with the baseline spectra, the progress of the dissolution could be tracked. In addition to the in-cell spectrophotometer analysis, an aliquot was taken for laboratory analysis from a sample collected from each of the 1-h-interval samples. To reduce the radiation dose to personnel, an incell dilution was prepared by collecting a $50-\mu \mathrm{L}$ aliquot of the anolyte sample and adding it to $5.0 \mathrm{~mL}$ of $1 \mathrm{MHNO}_{3}$.

After the 3-h sample was collected, the in-cell spectra analysis indicated that there was little change between the 2- and 3-h samples. Consequently, the digestion was stopped. The solution was cooled and transferred to a $500-\mathrm{mL}$ volumetric flask through the $2-\mu \mathrm{m}$ filter. The dissolution vessel was flushed with two washes $(\sim 100 \mathrm{~mL})$ of $4 \mathrm{MHNO}_{3}$, which were also filtered and added to the volumetric flask. After the volume in the volumetric flask was adjusted to $500 \mathrm{~mL}$, the solution was mixed and sampled for analysis. This sample was prepared by collecting a $50-\mu \mathrm{L}$ aliquot of the anolyte sample and adding it to $5.0 \mathrm{~mL}$ of $1 \mathrm{M} \mathrm{HNO}_{3}$. The samples that were collected during the CEPOD dissolution and the final acid product sample were submitted to the laboratory for analysis. 


\section{RESULTS}

\subsection{LABORATORY ANALYSES OF SAMPLES}

The analytical results and the analytical error from the laboratory analyses for alpha and gamma activities are shown in Table 2. The entry "ND" indicates either that a particular isotope was not present or that its activity was lower than the minimum detectable limit. Raw data from the sample analyses are shown in Appendix A.

\subsubsection{Gross Alpha Analyses}

The gross alpha activity in the CEPOD dissolution sample results was presumed to result from the activity of ${ }^{238} \mathrm{Pu}$. The results (Table 2) indicate that the dissolution was slowing (i.e., the activity difference between the 2- and 3-h samples was less than the activity difference between the 1- and 2-h samples). However, because the activity was still increasing, the results also indicate that the dissolution may have been incomplete. The dissolution was stopped based on analysis results obtained from the spectrophotometer, which showed little change between the 2- and 3-h samples. Further development work with the spectrophotometer is needed to determine the instrument's ability to resolve differences in concentration. Until then, for future dissolutions, it will be recommended that the digestion period be continued for at least an hour after the spectrophotometer data indicate that the dissolution is complete.

A discrepancy is noted in the gross alpha results between the results obtained for the final acid product sample and the intermediate dissolution samples. As shown in Table 2, the total activity (in becquerels) in the 2- and the 3-h intermediate dissolution samples is higher than that in the final acid product. Calculations for the masses of ${ }^{238} \mathrm{Pu}$ based on the alpha activity in the 3-h and final acid product samples resulted in quantities of 72 and $53 \mathrm{mg}$, respectively. Calculation of the mass of ${ }^{238} \mathrm{Pu}$ in the final acid product based on results obtained from inductively coupled plasma (ICP) analysis indicates that the mass of ${ }^{238} \mathrm{Pu}$ was $56 \mathrm{mg}$ (see Sect. 5.1.3). Therefore, the gross alpha analysis for the final acid product is likely to be more accurate than the gross alpha analysis for the intermediate dissolution samples. Because the samples were obtained and submitted for analysis in a similar manner, it is not known why the difference occurred.

\subsubsection{Gamma Analyses}

The analytical results for the fission products (e.g., ${ }^{144} \mathrm{Ce},{ }^{60} \mathrm{Co}$ ) in the various samples are shown in Table 2. The results in Table 2 also include the corresponding content for the various radionuclides on a 
Table 2. Alpha and gamma activity results from laboratory analysis of samples

\begin{tabular}{|c|c|c|c|c|c|}
\hline \multirow{2}{*}{$\begin{array}{c}\text { Analysis } \\
\text { performed }^{a}\end{array}$} & \multirow[b]{2}{*}{ Caustic dejacket } & \multicolumn{3}{|c|}{ Intermittent dissolution samples $^{b}$} & \multirow{2}{*}{$\begin{array}{c}\text { Final acid } \\
\text { product }\end{array}$} \\
\hline & & After $1 \mathrm{~h}$ & After $2 \mathrm{~h}$ & After $3 \mathrm{~h}$ & \\
\hline \multicolumn{6}{|l|}{ Gross alpha } \\
\hline Result, $\mathrm{Bq}$ & $4.0 \mathrm{E}+07$ & $2.8 \mathrm{E}+10$ & $3.9 \mathrm{E}+10$ & $4.5 \mathrm{E}+10$ & $3.3 \mathrm{E}+10$ \\
\hline Error, $\mathrm{Bq}$ & $1.0 \mathrm{E}+06$ & $3.0 \mathrm{E}+08$ & $3.0 \mathrm{E}+09$ & $3.0 \mathrm{E}+09$ & $5.1 \mathrm{E}+08$ \\
\hline \multicolumn{6}{|l|}{ Ce-144 } \\
\hline Result, $\mathrm{Bq}$ & ND & $3.9 \mathrm{E}+08$ & $6.1 \mathrm{E}+08$ & $5.8 \mathrm{E}+08$ & $3.8 \mathrm{E}+08$ \\
\hline Error, $\mathrm{Bq}$ & ND & $3.0 \mathrm{E}+07$ & $3.0 \mathrm{E}+07$ & $3.0 \mathrm{E}+07$ & $3.0 \mathrm{E}+07$ \\
\hline Result, g-mol & ND & -------- & -------- & -------- & $2.2 \mathrm{E}-08$ \\
\hline \multicolumn{6}{|l|}{ Co- 60} \\
\hline Result, Bq & $6.0 \mathrm{E}+04$ & $8.8 \mathrm{E}+06$ & $1.4 \mathrm{E}+07$ & $1.2 \mathrm{E}+07$ & $6.6 \mathrm{E}+06$ \\
\hline Error, $\mathrm{Bq}$ & $5.0 \mathrm{E}+04$ & $2.1 \mathrm{E}+06$ & $2.7 \mathrm{E}+06$ & $2.7 \mathrm{E}+06$ & $2.5 \mathrm{E}+06$ \\
\hline Result, g-mol & $2.4 \mathrm{E}-11$ & -------- & -------- & -------- & $2.6 \mathrm{E}-09$ \\
\hline \multicolumn{6}{|l|}{ Cs-134 } \\
\hline Result, Bq & $1.4 \mathrm{E}+07$ & $7.0 \mathrm{E}+06$ & $9.1 \mathrm{E}+06$ & $1.1 \mathrm{E}+07$ & $9.1 \mathrm{E}+06$ \\
\hline Error, $\mathrm{Bq}$ & $5.0 \mathrm{E}+05$ & $1.8 \mathrm{E}+06$ & $3.3 \mathrm{E}+06$ & $2.4 \mathrm{E}+06$ & $2.5 \mathrm{E}+06$ \\
\hline Result, g-mol & $2.1 \mathrm{E}-09$ & -------- & -------- & -------- & $1.4 \mathrm{E}-09$ \\
\hline \multicolumn{6}{|l|}{ Cs-137 } \\
\hline Result, Bq & $3.8 \mathrm{E}+08$ & $1.8 \mathrm{E}+08$ & $2.9 \mathrm{E}+08$ & $3.0 \mathrm{E}+08$ & $2.0 \mathrm{E}+08$ \\
\hline Error, $\mathrm{Bq}$ & $5.0 \mathrm{E}+06$ & $9.1 \mathrm{E}+06$ & $9.1 \mathrm{E}+06$ & $1.2 \mathrm{E}+07$ & $1.0 \mathrm{E}+07$ \\
\hline Result, g-mol & $8.6 \mathrm{E}-07$ & -------- & -------- & -------- & 4.6E-07 \\
\hline \multicolumn{6}{|l|}{ Eu-154 } \\
\hline Result, $\mathrm{Bq}$ & ND & ND & ND & $7.9 \mathrm{E}+06$ & ND \\
\hline Error, $\mathrm{Bq}$ & ND & ND & ND & $3.9 \mathrm{E}+06$ & ND \\
\hline Result, g-mol & ND & -------- & -------- & -------- & ND \\
\hline \multicolumn{6}{|l|}{ Eu-155 } \\
\hline Result, $\mathrm{Bq}$ & ND & $2.0 \mathrm{E}+07$ & $5.2 \mathrm{E}+07$ & $2.8 \mathrm{E}+07$ & $3.4 \mathrm{E}+07$ \\
\hline Error, $\mathrm{Bq}$ & ND & $5.8 \mathrm{E}+06$ & $6.1 \mathrm{E}+06$ & $7.6 \mathrm{E}+06$ & $6.1 \mathrm{E}+06$ \\
\hline Result, g-mol & ND & -------- & -------- & -------- & $1.3 \mathrm{E}-08$ \\
\hline \multicolumn{6}{|l|}{ Ru-106 } \\
\hline Result, Bq & $1.2 \mathrm{E}+08$ & $1.1 \mathrm{E}+07$ & ND & $2.9 \mathrm{E}+07$ & ND \\
\hline Error, $\mathrm{Bq}$ & $5.0 \mathrm{E}+06$ & $1.2 \mathrm{E}+07$ & ND & $2.2 \mathrm{E}+07$ & ND \\
\hline Result, g-mol & 8.9E-09 & -------- & -------- & -------- & ND \\
\hline \multicolumn{6}{|l|}{ Sb-125 } \\
\hline Result, Bq & $6.0 \mathrm{E}+06$ & $1.6 \mathrm{E}+07$ & ND & $1.5 \mathrm{E}+07$ & ND \\
\hline Error, $\mathrm{Bq}$ & $1.5 \mathrm{E}+06$ & $7.9 \mathrm{E}+06$ & ND & $9.4 \mathrm{E}+06$ & ND \\
\hline Result, g-mol & $1.2 \mathrm{E}-09$ & -------- & -------- & -------- & ND \\
\hline \multicolumn{6}{|l|}{ Total activity $^{c}$} \\
\hline Result, $\mathrm{Bq}$ & $8.0 \mathrm{E}+08$ & $3.0 \mathrm{E}+10$ & $4.8 \mathrm{E}+10$ & $5.2 \mathrm{E}+10$ & $3.6 \mathrm{E}+10$ \\
\hline Error, $\mathrm{Bq}$ & $5.0 \mathrm{E}+07$ & $3.0 \mathrm{E}+09$ & $3.0 \mathrm{E}+09$ & $3.0 \mathrm{E}+09$ & $5.1 \mathrm{E}+08$ \\
\hline
\end{tabular}

${ }^{a}$ The entry "ND" indicates that the radionuclide was not present or that its concentration was below the minimum detection limit. The "g-mol" values were calculated only for the caustic dejacket and the final acid product solutions.

${ }^{b}$ The time is referenced to the time at which the temperature of the solution reached $60^{\circ} \mathrm{C}$.

${ }^{c}$ Measured value that includes activity from all sources (i.e., alpha, beta, and gamma). 
gram-mole basis for the caustic dejacket and final acid product samples. These results show that $\sim 64$ and $36 \%$ (gram-mole basis) of the fission products ended up in the caustic dejacket and the final acid product solutions, respectively. Summing the fission products for the caustic dejacket and final acid product results and comparing them with the original neptunium content indicate that $0.04 \%$ (gram-mole basis) of the neptunium was converted to fission products during the irradiation process. The major contributors to activity in the caustic dejacket solution were from the fission products, including $\sim 47.5 \%$ of the activity from ${ }^{137} \mathrm{Cs}$. Approximately $91.7 \%$ of the activity in the final acid product solution was from alpha activity (primarily ${ }^{238} \mathrm{Pu}$ ).

\subsubsection{ICP Analyses}

Samples of the caustic dejacketing solution and the final acid product were analyzed for metal content by ICP. The results, which are shown in Table 3, showed that $98.9 \%$ of the neptunium and $99.8 \%$ of the plutonium were in the final acid product (see Appendix A for raw analytical results). Minor quantities of ${ }^{239} \mathrm{Pu},{ }^{240} \mathrm{Pu}$, and ${ }^{234} \mathrm{U}$ were present in both solutions; however, the acid product contained the major portion of these radionuclides. The final acid product contained $62.3 \mathrm{mg}$ of plutonium and $596 \mathrm{mg}$ of neptunium. The caustic dejacket solution contained $0.14 \mathrm{mg}$ of plutonium and $6.55 \mathrm{mg}$ of neptunium. The neptunium in the final acid product and the caustic dejacket solution represents $78.9 \%$ of the original mass of neptunium in the pellets prior to irradiation (see Table 1). Assuming that all of the plutonium was recovered, the results indicate that the irradiation of the pellets converted $8.14 \%$ (gram-mole basis) of the neptunium to plutonium.

Table 3. ICP results from laboratory analysis of samples

\begin{tabular}{ccc}
\hline & \multicolumn{2}{c}{ Mass (mg) } \\
\cline { 2 - 3 } Isotope & $\begin{array}{c}\text { Caustic } \\
\text { dejacket }\end{array}$ & $\begin{array}{c}\text { Final acid } \\
\text { product }\end{array}$ \\
\hline Np-237 & 6.55 & 596 \\
Pu-238 & 0.10 & 56.1 \\
Pu-239 & 0.03 & 5.86 \\
Pu-240 & 0.01 & 0.40 \\
U-234 & 0.13 & 1.52 \\
\hline
\end{tabular}




\subsection{SPECTROPHOTOMETER ANALYSIS OF SAMPLES}

Three samples were taken during the dissolution and analyzed in a $1-\mathrm{cm}$ cell with a Cary $17 \mathrm{DH}$ spectrophotometer. The presence of neptunium(VI) and plutonium(VI) was clearly shown by their absorbance bands at $\sim 1210$ and $830 \mathrm{~nm}$, respectively. No other actinide valence states were observed (as expected under these oxidative dissolution conditions). Peak heights for each band were approximately 0.4 absorbance units. The cerium(IV) absorbed strongly below $550 \mathrm{~nm}$. The scans for all three samples were nearly the same but showed very slight increases as the dissolution proceeded.

Because the plutonium(VI) band is very narrow and therefore difficult to resolve, resolution checks were performed to determine if this band had been properly resolved. Under standard scanning conditions, the band height was $\sim 0.4$. Changing to much higher resolution conditions produced no increase in the band height, showing that the standard conditions were adequate. Qualitatively, the intensities measured are in line with the amount of pellet dissolved. 


\section{SUMMARY AND RECOMMENDATIONS}

This project demonstrated the feasibility of using the CEPOD process to dissolve neptunium pellets. The advantage of this dissolution method is that the dissolution of the recalcitrant oxides was accomplished by attack of cerium(IV) ions. The baseline method for accomplishing the dissolution is to add fluoride ions. Although fluoride ions are effective at dissolving the compounds, they are undesirable constituents in the process because they are very corrosive and cause problems with the in-line spectrophotometric measurements used to monitor valences in the subsequent purification processes. The results demonstrated that the CEPOD process was effective at dissolving the irradiated pellets.

Literature findings had indicated that fission products such as ruthenium could pose a problem for the CEPOD process because the ruthenium was a strong reductant and would quickly react with the cerium(IV) ions to reduce them to cerium(III), which is not effective at dissolving the oxides. ${ }^{2}$ However, no apparent problems were attributed to ruthenium. The concentration of ruthenium in the targets was low, and a large portion $(\sim 80 \%)$ of the ruthenium was separated from the targets during the first processing step (i.e., removal of the aluminum jacket). Although the ruthenium ions react with the cerium(IV) ions to convert them to cerium(III) ions, the cerium(IV) ions oxidize the ruthenium ions to a higher valence state at which they become nonreactive with the cerium(IV). The CEPOD process continuously regenerates the cerium(III) ions to the cerium(IV) condition. As a result, even though the ruthenium initially reacts with the cerium(IV) ions, the reductive state of the ruthenium ions is eventually depleted.

The data obtained from this study indicate that additional development work for the CEPOD process should be performed with additional targets. Operational recommendations include collecting samples at more frequent intervals, particularly during the early part of the dissolution and especially for in-cell analysis via the spectrophotometer. Other operational recommendations include determining if the dissolution can be completed at lower concentrations of cerium, thus reducing material costs for the cerium as well as disposal costs (i.e., less waste). However, the reduction in the cerium concentration may be most beneficial in improving the effectiveness of the processing steps for purifying the neptunium and plutonium compounds.

The testing with the in-cell spectrophotometer system indicated that it was a good tool for monitoring the presence of the neptunium and plutonium species in the intermittent dissolution samples as well as the final product. Additional work needs to be done with the spectrophotometer and process solutions to 
determine the resolution ability (i.e., concentration differences) of the instrument. The spectrophotometer could be used to minimize the amount of time that is required for dissolving these types of materials. One can also envision an on-line system for continuously monitoring the concentration of plutonium and neptunium in near real time. The development of this type of system with the spectrophotometer should be explored. 


\section{REFERENCES}

1. A. S. Icenhour, R. M. Wham, R. R. Brunson, and R. R. McMahon, Post-Irradiation Examination of Array Targets - Part I, ORNL/TM-2003/220, Oak Ridge National Laboratory, Oak Ridge, Tennessee, Dec. 2003.

2. D. E. Horner, D. J. Crouse, and J. C. Mailen, Cerium-Promoted Dissolution of $\mathrm{PuO}_{2}$ and $\mathrm{PuO}_{2}-\mathrm{UO}_{2}$ in Nitric Acid, ORNL/TM-4716, Oak Ridge National Laboratory, Oak Ridge, Tennessee, 1977.

3. J. L. Ryan, L. A. Bray, E. J. Wheelwright, and G. H. Bryan, "Catalyzed Electrolytic Plutonium Oxide Dissolution: The Past 17 Years and Future Potential," in Transuranium Elements: A Half Century, L. R. Morss, and J. Fuger, eds., American Chemical Society, Washington, D.C, 1992.

4. R. M. Wham, et al., Summary Report of Pellet Target Fabrication and Irradiation in the High Flux Isotope Reactor (HFIR) and the Advanced Test Reactor (ATR), ORNL/TM-2004/170, Oak Ridge National Laboratory, Oak Ridge, Tennessee, 2004.

5. R. M. Wham, A. S. Icenhour, W. D. Bond, R. R. Brunson, T. D. Hylton, and L. M. Toth, Development and Evaluation Study for the Production of ${ }^{238} \mathrm{Pu}$, ORNL/TM-2004/174, Oak Ridge National Laboratory, Oak Ridge, Tennessee, 2004.

6. D. A. Costanzo, R. E. Biggers, and J. T. Bell, "Plutonium Polymerization-I: A Spectrophotometric Study of the Polymerization of Plutonium(IV)," J. Inorg. Nucl. Chem. 35, 609-622 (1973).

7. L. M. Toth and H. A. Friedman, "Absorption Spectra of Np(III), (IV), (V) and (VI) in Nitric Acid Solution,” J. Inorg. Nucl. Chem. 42, 1347-1349 (1980). 

APPENDIX A

ANALYTICAL SAMPLE RESULTS 



\section{APPENDIX A. ANALYTICAL SAMPLE RESULTS}

Samples that were submitted to the analytical laboratory were analyzed for activity and metal content.

Table A.1 provides the basic parameters that were applied to the raw laboratory sample data.

Table A.1. Basic parameters that were applied to laboratory sample results

\begin{tabular}{lcc}
\hline Sample identification & Dilution factor $^{a}$ & Volume basis (mL) $^{-}$ \\
\hline Caustic dejacketing solution & 1 & 500 \\
CEPOD: 1-h digestion & 101 & 300 \\
CEPOD: 2-h digestion & 101 & 300 \\
CEPOD: 3-h digestion & 101 & 300 \\
Acid product & 101 & 500 \\
\hline
\end{tabular}

${ }^{a}$ Actinide dissolution solutions were diluted $50 \mu \mathrm{L}$ in $5 \mathrm{~mL}$ of $1 M \mathrm{HNO}_{3}$ prior to submitting to laboratory. The caustic dejacketing sample was submitted to the laboratory without dilution.

Tables A.2 and A.3 show the laboratory results and error data obtained for the activity (alpha and gamma) and ICP analyses, respectively. 
Table A.2. Laboratory results from alpha and gamma activity analyses

\begin{tabular}{|c|c|c|c|c|c|}
\hline \multirow{2}{*}{$\begin{array}{c}\text { Analysis } \\
\text { performed }^{a, b}\end{array}$} & \multirow{2}{*}{$\begin{array}{c}\text { Caustic } \\
\text { dejacket }\end{array}$} & \multicolumn{3}{|c|}{ Intermittent dissolution samples ${ }^{c}$} & \multirow{2}{*}{$\begin{array}{r}\text { Final acic } \\
\text { product }\end{array}$} \\
\hline & & After $1 \mathrm{~h}$ & After $2 \mathrm{~h}$ & After $3 \mathrm{~h}$ & \\
\hline \multicolumn{6}{|l|}{$\begin{array}{l}\text { Gross alpha } \\
\text {. }\end{array}$} \\
\hline Result, $\mathrm{Bq} / \mathrm{mL}$ & $8.0 \mathrm{E}+04$ & $9.4 \mathrm{E}+05$ & $1.3 \mathrm{E}+06$ & $1.5 \mathrm{E}+06$ & $6.6 \mathrm{E}+05$ \\
\hline Error, $\mathrm{Bq} / \mathrm{mL}$ & $2.0 \mathrm{E}+03$ & $1.0 \mathrm{E}+04$ & $1.0 \mathrm{E}+05$ & $1.0 \mathrm{E}+05$ & $1.0 \mathrm{E}+04$ \\
\hline \multicolumn{6}{|l|}{$\mathrm{Ce}-144$} \\
\hline Result, $\mathrm{Bq} / \mathrm{mL}$ & ND & $1.3 \mathrm{E}+04$ & $2.0 \mathrm{E}+04$ & $1.9 \mathrm{E}+04$ & $7.5 \mathrm{E}+03$ \\
\hline Error, $\mathrm{Bq} / \mathrm{mL}$ & ND & $1.0 \mathrm{E}+03$ & $1.0 \mathrm{E}+03$ & $1.0 \mathrm{E}+03$ & $6.0 \mathrm{E}+02$ \\
\hline \multicolumn{6}{|l|}{ Co- 60} \\
\hline Result, $\mathrm{Bq} / \mathrm{mL}$ & $1.2 \mathrm{E}+02$ & $2.9 \mathrm{E}+02$ & $4.5 \mathrm{E}+02$ & $4.1 \mathrm{E}+02$ & $1.3 \mathrm{E}+02$ \\
\hline Error, $\mathrm{Bq} / \mathrm{mL}$ & $1.0 \mathrm{E}+02$ & $7.0 \mathrm{E}+01$ & $9.0 \mathrm{E}+01$ & $9.0 \mathrm{E}+01$ & $5.0 \mathrm{E}+01$ \\
\hline \multicolumn{6}{|l|}{ Cs-134 } \\
\hline Result, Bq/mL & $2.7 \mathrm{E}+04$ & $2.3 \mathrm{E}+02$ & $3.0 \mathrm{E}+02$ & $3.7 \mathrm{E}+02$ & $1.8 \mathrm{E}+02$ \\
\hline Error, $\mathrm{Bq} / \mathrm{mL}$ & $1.0 \mathrm{E}+03$ & $6.0 \mathrm{E}+01$ & $1.1 \mathrm{E}+02$ & $8.0 \mathrm{E}+01$ & $5.0 \mathrm{E}+01$ \\
\hline \multicolumn{6}{|l|}{ Cs-137 } \\
\hline Result, $\mathrm{Bq} / \mathrm{mL}$ & $7.6 \mathrm{E}+05$ & $5.8 \mathrm{E}+03$ & $9.5 \mathrm{E}+03$ & $9.8 \mathrm{E}+03$ & $4.0 \mathrm{E}+03$ \\
\hline Error, $\mathrm{Bq} / \mathrm{mL}$ & $1.0 \mathrm{E}+04$ & $3.0 \mathrm{E}+02$ & $3.0 \mathrm{E}+02$ & $4.0 \mathrm{E}+02$ & $2.0 \mathrm{E}+02$ \\
\hline \multicolumn{6}{|l|}{ Eu-154 } \\
\hline Result, $\mathrm{Bq} / \mathrm{mL}$ & ND & ND & ND & $2.6 \mathrm{E}+02$ & ND \\
\hline Error, $\mathrm{Bq} / \mathrm{mL}$ & ND & ND & ND & $1.3 \mathrm{E}+02$ & ND \\
\hline \multicolumn{6}{|l|}{ Eu-155 } \\
\hline Result, $\mathrm{Bq} / \mathrm{mL}$ & ND & $6.6 \mathrm{E}+02$ & $1.7 \mathrm{E}+03$ & $9.4 \mathrm{E}+02$ & $6.7 \mathrm{E}+02$ \\
\hline Error, Bq/mL & ND & $1.9 \mathrm{E}+02$ & $2.0 \mathrm{E}+02$ & $2.5 \mathrm{E}+02$ & $1.2 \mathrm{E}+02$ \\
\hline \multicolumn{6}{|l|}{$\mathrm{Ru}-106$} \\
\hline Result, $\mathrm{Bq} / \mathrm{mL}$ & $2.3 \mathrm{E}+05$ & $3.5 \mathrm{E}+02$ & ND & $9.6 \mathrm{E}+02$ & ND \\
\hline Error, $\mathrm{Bq} / \mathrm{mL}$ & $1.0 \mathrm{E}+04$ & $4.0 \mathrm{E}+02$ & ND & $7.3 \mathrm{E}+02$ & ND \\
\hline \multicolumn{6}{|l|}{$\mathrm{Sb}-125$} \\
\hline Result, $\mathrm{Bq} / \mathrm{mL}$ & $1.2 \mathrm{E}+04$ & $5.4 \mathrm{E}+02$ & ND & $5.0 \mathrm{E}+02$ & ND \\
\hline Error, $\mathrm{Bq} / \mathrm{mL}$ & $3.0 \mathrm{E}+03$ & $2.6 \mathrm{E}+02$ & ND & $3.1 \mathrm{E}+02$ & ND \\
\hline \multicolumn{6}{|l|}{ Total activity $^{d}$} \\
\hline Result, $\mathrm{Bq} / \mathrm{mL}$ & $1.6 \mathrm{E}+06$ & $1.0 \mathrm{E}+06$ & $1.6 \mathrm{E}+06$ & $1.7 \mathrm{E}+06$ & $7.2 \mathrm{E}+05$ \\
\hline Error, $\mathrm{Bq} / \mathrm{mL}$ & $1.0 \mathrm{E}+05$ & $1.0 \mathrm{E}+05$ & $1.0 \mathrm{E}+05$ & $1.0 \mathrm{E}+05$ & $1.0 \mathrm{E}+04$ \\
\hline
\end{tabular}

${ }^{a}$ The entry "ND" indicates that the radionuclide was not present or that its concentration was below the minimum detection limit.

${ }^{b}$ See Table A.1 for dilution factor and volume basis data for the various samples.

${ }^{c}$ The time is referenced to the time at which the temperature of the solution reached $60^{\circ} \mathrm{C}$.

${ }^{d}$ Measured value that includes activity from all sources (i.e., alpha, beta, and gamma). 
Table A.3. Laboratory results from ICP analyses

\begin{tabular}{ccc}
\hline & \multicolumn{2}{c}{${\text { Result }(\mathrm{ng} / \mathrm{mL})^{a}}^{a}$} \\
\cline { 2 - 3 } Radionuclide & Caustic dejacket & Final acid product \\
\hline Np-237 & 13,100 & 11,800 \\
Pu-238 & 203 & 1,110 \\
Pu-239 & 57 & 116 \\
Pu-240 & 10 & 8 \\
U-234 & 255 & 30 \\
\hline
\end{tabular}

${ }^{a}$ See Table A.1 to obtain dilution factor and volume basis to apply to these results. 

ORNL/TM-2004/211

\section{INTERNAL DISTRIBUTION}

1. C. W. Alexander

2. W. D. Bond

3-4. R. R. Brunson

5. E. D. Collins

6. G. D. Del Cul

7. L. K. Felker

8. M. A. Green

9. J. N. Herndon

10. D. J. Hill

11-15. T. D. Hylton

16-17. A. S. Icenhour

18. R. T. Jubin

19. J. M. Keller
20. B. E. Lewis

21. S. C. Marschman

22. B. D. Patton

23. J. E. Rushton

24. C. M. Simmons

25. D. W. Simmons

26. B. B. Spencer

27-28. L. M. Toth

29. L. D. Trowbridge

30-32. R. M. Wham

33. D. F. Williams

34. NSTD DMC

35. OTIC-RC, OSTI, CRL

\section{EXTERNAL DISTRIBUTION}

36. L. W. Boyd, DOE-ORO, U.S. Department of Energy, P.O. Box 2008 MS-6269, Oak Ridge, TN 37831

37. W. P. Carroll, DOE-HQ, NE-40/Germantown Building, U.S. Department of Energy, 1000 Independence Ave., S. W., Washington, DC 20585-1290

38. S. R. Martin, Jr., DOE-ORO, U.S. Department of Energy, P.O. Box 2008 MS-6269, Oak Ridge, TN 37831

39. B. G. Schnitzler, Idaho National Engineering and Environmental Laboratory, P.O. Box 1625, Idaho Falls, ID 83415 